\title{
Könyvszemle
}

SIPOS JÚLIA GONDOZÁSÁBAN

\section{VÁLOGATÁS HARGITTAI ISTVÁN ÍRÁSAIBÓL}

„Ha a tudományt zárt birodalomnak tekintjük, amely túlságosan elvont és bonyolult ahhoz, hogy az átlagember megérthesse, akkor a helytelen alkalmazás veszélyei nagyobbak. Ha viszont a széles közvélemény érdeklődik a tudományok iránt és törődik az eredményekkel - ha a természettudomány szépségét és társadalmi következményeit is sokkal gyakrabban tárgyaljuk az iskolákban éppúgy, mint a médiában vagy éppen az ebédlőasztalnál -, akkor sokkal kedvezőbbek lesznek az esélyeink, hogy megtudjuk, milyen valójában a világunk. Ezzel együtt a siker reményében próbálkozhatunk, hogy a magunk javára jobbá tegyük.” (Carl Sagan, amerikai asztrobiológus és ismeretterjesztő)

Amikor kedves barátom, Hargittai István akadémikus felkért, hogy írjak recenziót a Tudományos felfedezések kultúrája és müvészete címü angol nyelvü enciklopédiájáról, őszinte és nagy megtiszteltetést éreztem. Amikor megkaptam az A4-es formátumú, szószedet nélkül is 470 oldalas könyvet, és átlapoztam, már meglehetősen elbátortalanodtam. Amikor viszont majd egy hónapja elkezdtem elmélyedni ebben a gigantikus összeállításban, már tudtam, hogy erről a hatalmas opusról én egyszerüen nem tudok, talán nem is lehet méltó és tárgyszerü ismertetést írni.

Impresszióim, érzéseim, asszociációim keletkeztek erről a lenyügöző életmüröl. Nem is a félszáznál is több világhírü természettudós káprázatos tudománya jelenti ezt a magasságot, hanem az a sokcsúcsú piramis, amit Hargittai István szintetikus rálátó igényessége és embersége az olvasó elé tár. Természetesen, mint kutató molekuláris biológus azonnal villódzni kezdtek a nevek, Arthur Kornberg, Francis Crick, David Baltimore, Sydney Brenner, Erwin Chargaff, Renato Dulbecco, Teller Ede, Wigner Jenő, Craig Venter, James Watson, Dmitrij Mengyelejev, Avram Hershko, hogy szinte csak találomra néhány óriás nevét említsem. De vannak itt mások is, akiknek életmüve egy-egy fényes fejezetet jelent a tágabb skálájú természettudományos arzenálban.

Hargittai István és ihlető társa, Magdi is jelen vannak a beszélgetéseken. Ök nem a formális interjúért, a „nagyember” egy-egy információmorzsájáért esdeklö sznob módon dokumentáló személyek. A leírások, az interjúk kétséget sem 
hagynak Hargittaiék felkészült tudásából, alapos és személyes, elmélyült ismereteikből, abból az elegáns tiszteletből, ami meg is illeti a megszólítottakat. Ugyanakkor, a megközelítés egy másik tudós egyenrangú barátságának a gesztusait sugallja. Hargittai beemeli az olvasót a szituációba, helyettünk kérdez, és helyettünk hallgatja a válaszokat, történeteket. Ott vagyunk szinte mi is - mint érdeklődő és kíváncsi olvasók -, „tegező” viszonyba kerülünk a méltán hírességgel. Aki persze szerény (mondhatni Hofi után, hogy van mire), és érzékelhetően jobban is érzi magát a tudomány egyenrangú képviselöjével, mint ha egy bálványságra kárhoztatott piedesztálról lesnék a szónoklatát. Érdemi, tanulságos mondanivalójú emberekkel találkozhatunk, akik ilyen-olyan háttérrel, életúttal és sorssal partnerekként vesznek részt a beszélgetésekben. Nem kinyilatkoztatnak, hanem beszélgetnek. Hargittai István láthatóan örömet szerez nekik, többeknek, mint a híres Candid Science képviselőinek, azért is, mert a tiszteletét méltósággal és intelligens tudással képviselő partnernek nyílhatnak meg.

Tudomány és müvészet, erről a két fogalomról sokunknak Leonardo da Vinci jut elsőre eszünkbe. A Leonardo nevű folyóiratra történő többszörös hivatkozások mellett örömmel fedezzük fel a zseniális müvész és tudós Luca Paciolinak rajzolt híres csonkolt icozahedronját.

E könyvböl tudtam meg, hogy Hargittai István a Journal of Chemical Education címü folyóirat címlapjának rendszeres tervezője volt. A rotációs izomerek alakjáról Hargittai István Edgar Degas nyúlánk táncosnőit asszociálja, más szimmetriák formai analógiáiként magyar népi szőttesek mintáját mutatja be, ugyanúgy, ahogy egy polimer molekula hasonlatosságát láttatja Magdolnával együtt írt, a Symmetry through the Eyes of a Chemist címü könyvükben. Egy Wiley-kiadványban alkotó módon veszi észre egy régi erdélyi hímzésben a kémiai konfigurációkra emlékeztető kis madárkamotívumokat.

Hargittai úgy szemléli a világot, annak művészi alkotásait, hogy közben ízig-vérig szerkezetkutató kémikus, illetve tágabban tekintve természettudós marad. A madridi és a pekingi oroszlánok talpa alatti gömbformákban fullerén alakzatokat vizualizál. Hasonlóan a pentagonális-hexagonális kőformálásokról Hargittainak a szuperstabil C60-struktúrák idéződnek fel. Tükröződő formáknál eszébe jutnak a magyar batikolt minták, sőt még a Tungsram-logó is. Mint a hatvanas évek elején eszmélő fiatal biológuspalánta a DNS kettős helikális ábrázolásairól és annak müvészi képi narratíváiról nem is beszélek.

Hargittai látásmódja egyszerre a szenvedélyes szerkezetkutató kémikus és a múvészeti absztrakciókra érzékeny polihisztor ember víziója a világról. Nem hagyja közömbösen a Mackay-féle polihedron szerkezetủ pentagonális hópelyhek fraktálszimmetriája sem.

A kötetben többször találkozunk Orosz István kitünő és nagyon egyéni grafikáival, aki Hargittai tudóstársainak (Oláh György, Pierre Curie, Aleksander Kitaigorodski) portréját alkotta meg sajátos egyéni ábrázolásaival. 
Valahol olvastam, hogy a tapasztalatból született ismeret gépies, és csak az az ismeret tudományos, amely az elmében születik, és ott végződik. Az elme és a lélek harmóniájában lépésnyi távolságra van a mủvészet, minden emberi tevékenység legihletettebb megnyilvánulása.

Hargittai István és Hargittai Magdolna fia, Balázs, a könyv szerkesztője bevezetőjében így ír apjáról és gyerekkoráról:

„...élvezet volt ebben a családban felnőni, de ez egyben meglehetősen nagy igényeket is támasztott irányunkban... [szüleink] mindig azt mondták nekünk, hogy boldognak akarnak látni bennünket, ami nem feltétlenül kell, hogy jelentse a világban való sikerességet... Ez az összeállítás jól tükrözi István életének sokszínü aktivitását ... bepillantást enged mások érdeklődésébe és kétségeibe is a XX-XXI. század fordulóján... Minthogy a tudományos eredmények egyre gyorsabban évülnek el, lehet, hogy ez a »mellékterméke« [apám] életének időtállóbb lesz, mint kutatási eredményei..."

Kedves Balázs, mint e remek enciklopédikus igényességü könyv ismertetője, miközben őszintén gratulálok ehhez a fantasztikus kiadványhoz, teljes tisztelettel és egyben határozottsággal ezzel az utolsó megállapításoddal nem értek egyet. Hargittai István egész motivációjában, empatikus gesztusaiban, beszélgetéseiben, müvészi látásában és vonzódásában igenis elválaszthatatlanul benne volt a tudomány szeretete, pontosabban a szépség meglátása a kutatói életpálya egyes elemeiben. Így és csak így tudott ennyire hiteles és igaz ismeretségekre szert tenni, és azokat ennyire beavatóan átadni olvasóinak.

„Ne félj csodálkozni. Ne félj kérdezni mások szerint furcsa kérdéseket, mondjuk »Miért kék az ég?«. Ezekben a kérdésekben érdekes válasz rejlik, mert ez az, amiröl a természettudomány szól, megérteni a természetet, és nem félni feltenni azt a kérdést, hogy »Miért?«." (Amy Mainzer, amerikai csillagász és asztrofizikus)

(Balazs Hargittai editor: Culture and Art of Scientific Discoveries - A Selection of István Hargittai's Writings. Springer Nature Switzerland AG, 2019, xxiv+482 o.)

Falus András

az MTA rendes tagja 